Published in final edited form as:

Curr Protoc Mol Biol. ; 110: 4.23.1-4.23.17. doi:10.1002/0471142727.mb0423s110.

\title{
Current Protocols in Molecular Biology Unit 4.23:
}

\section{Mapping 3' mRNA isoforms on a genomic scale}

\author{
Yi Jin ${ }^{1}$, Joseph V. Geisberg ${ }^{1}$, Zarmik Moqtaderi ${ }^{1}$, Zhe $\mathrm{Ji}^{1}$, Mainul Hoque ${ }^{2}$, Bin $\mathrm{Tian}^{2}$, and \\ Kevin Struhl ${ }^{1}$ \\ ${ }^{1}$ Department of Biological Chemistry and Molecular Pharmacology, Harvard Medical School, \\ Boston, Massachusetts \\ ${ }^{2}$ Department of Microbiology, Biochemistry and Molecular Genetics, Rutgers New Jersey Medical \\ School, Newark, New Jersey
}

\begin{abstract}
Most eukaryotic genes are transcribed into mRNAs with alternative poly(A) sites. Emerging evidence suggests that mRNA isoforms with alternative poly(A) sites can perform critical regulatory functions in numerous biological processes. In recent years, a number of strategies utilizing high-throughput sequencing technologies have been developed to aid in the identification of genome-wide poly(A) sites. This unit describes a modified protocol of a recently published 3'READS (3' region extraction and deep sequencing) method that accurately identifies genomewide poly(A) sites and that can be used to quantify the relative abundance of the resulting 3' mRNA isoforms. This approach minimizes non-specific sequence reads due to internal priming and typically yields a high percentage of sequence reads that are ideally suited for accurate poly(A) identification.
\end{abstract}

\section{Keywords}

3' mRNA isoforms; polyadenylation; poly(A) sites; RNA sequencing

\section{INTRODUCTION}

Alternative 3' end formation adds an additional level of regulatory control to gene expression, and there is growing evidence for the importance of transcripts with alternative polyadenylation (poly(A)) sites in the regulation of a diverse number of biological processes (Elkon et al., 2013; Tian and Manley, 2013). These alternative poly(A) sites give rise to distinct 3' mRNA isoforms possessing 3' untranslated regions (UTRs) of different lengths. The individual mRNA isoforms have the potential to exhibit key biological differences, for example due to the presence or absence of sequences or structures important for their processing, export, or decay. Indeed, alternative 3' mRNA isoforms arising from the same gene can sometimes exhibit highly different stabilities (Geisberg et al., 2014).

The prevalence of alternative poly(A) sites means that a frequent objective in transcriptome analysis is the precise identification of mRNA 3' ends. In addition to identifying all the mRNA species arising from a particular gene, it is also often important to determine the relative abundance of the various isoforms. Common methods to identify poly(A) sites 
generally incorporate annealing of oligonucleotides to poly(A) tail, either by using oligo-dT priming from the poly(A) tail during the construction of DNA sequencing libraries or by direct annealing poly(A) tail to oligo-dT on the sequencing flow cell.

The basic protocol in this unit is modified from the procedure for 3' Region Extraction And Deep Sequencing (3'READS) (Hoque et al., 2013), developed for mapping genome-wide poly(A) sites and quantifying the relative abundance of the resulting 3' mRNA isoforms. At the heart of the procedure is the initial annealing of the mRNA poly(A) tails to a hybrid RNA/DNA oligonucleotide consisting of $5 \mathrm{U}$ and $45 \mathrm{~T}$ nucleotides. A subsequent digestion with RNase $\mathrm{H}$ cleaves only the RNA-DNA portion of the resulting duplex, leaving intact the $\sim 5$ bp of U-A in RNA-RNA duplex at the beginning of the poly(A) tail. This has the effect of preserving the junction between the poly(A) site and the poly(A) tail, allowing more precise mapping of the 3' boundary of the encoded mRNA after these fragments are amplified and sequenced. During the data analysis steps, the number of A bases at the 3' terminus of RNA is compared to the number of As encoded in the genome, and any terminal As not encoded in the genome are considered to be added during polyadenylation process.

\section{BASIC PROTOCOL CONSTRUCTING AN INDEXED DNA SEQUENCING LIBRARY FROM 3' mRNA ISOFORMS}

This section describes the detailed protocol for the creation of an indexed DNA library for sequencing poly(A) sites ( 3 ' mRNA isoforms) on a genome-wide scale on the Illumina sequencing platform. This protocol is modified from the published 3'READS method (Hoque et al., 2013; Hoque et al., 2014). The procedure is outlined in Figure 1.

Materials-25 $\mu \mathrm{g}$ purified total RNA (UNIT 4.1, 4.2, 4.3 and 4.16)

Oligonucleotides (see Table 1)

Oligo d(T) ${ }_{25}$ Magnetic Beads (NEB)

Dynabeads MyOne Streptavidin C1 (Invitrogen)

DNA SizeSelector-I (Aline)

Beads pre-wash buffer (see recipe)

2X Annealing buffer (see recipe)

$2 \mathrm{X}$ Coupling buffer (see recipe)

2X Hybridization buffer (see recipe)

High-stringency wash buffer (see recipe)

RNase III digestion buffer (see recipe)

RNase $\mathrm{H}$ digestion buffer (see recipe)

Curr Protoc Mol Biol. Author manuscript; available in PMC 2016 April 01. 
Elution buffer (see recipe)

TE buffer (see recipe)

Gel extraction buffer (see recipe)

$10 \mathrm{M} \mathrm{NaOH}($ APPENDIX 2)

$5 \mathrm{M} \mathrm{NaCl}$ (RNase-free; APPENDIX 2)

0.5 M EDTA (RNase-free; APPENDIX 2)

1 M Tris-Cl, pH7.5 (RNase-free; APPENDIX 2)

$1 \mathrm{M}$ Tris-Cl, pH8 (APPENDIX 2)

1 M Tris-Cl, pH8.3 (RNase-free; APPENDIX 2)

$1 \mathrm{M} \mathrm{MgCl}_{2}$ (RNase-free; APPENDIX 2)

1 M DTT (RNase-free; APPENDIX 2)

$3 \mathrm{M}$ sodium acetate, $\mathrm{pH} 5.5$ (RNase-free; APPENDIX 2)

TBE buffer (APPENDIX 2)

$1 \mathrm{U} / \mu \mathrm{l}$ RNase III (NEB)

5 U/ $\mu$ l RNase H (NEB)

2 U/ $\mu$ l Phusion HF DNA polymerase (NEB)

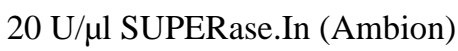

$10 \mathrm{U} / \mu \mathrm{l}$ T4 RNA ligase 1 (NEB)

$200 \mathrm{U} / \mu \mathrm{l}$ truncated T4 RNA ligase 2 (NEB)

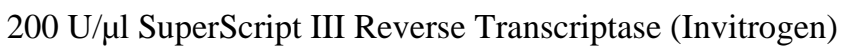

12.5 and $25 \mathrm{mM}$ dNTPs

Costar Spin-X centrifuge tube filter $(0.45-\mu \mathrm{m}$ cellulose acetate in 2 -ml tube; Corning)

$15 \mathrm{mg} / \mathrm{ml}$ GlycoBlue (Ambion)

Formamide, deionized (Ambion)

TWEEN 20 (Sigma)

10,000X SYBR Gold Nucleic Acid Gel Stain (Invitrogen)

Curr Protoc Mol Biol. Author manuscript; available in PMC 2016 April 01. 
Acid-Phenol:Chloroform, pH4.5 (Ambion)

$100 \%, 80 \%, 70 \%$ ethanol

Nuclease-free $\mathrm{H}_{2} \mathrm{O}$

Refrigerated centrifuge

Gel electrophoresis apparatus

8\% TBE polyacrylamide gel (Invitrogen)

100 bp DNA Ladder (NEB)

PCR Marker (NEB)

6X Gel Loading Dye, Blue (NEB)

20-gauge needles

Vortex

0.5-ml thin-walled PCR tubes (non-stick, Ambion)

1.5-ml microcentrifuge tubes (non-stick, Ambion)

Thermal cycler

$37^{\circ} \mathrm{C}, 55^{\circ} \mathrm{C}, 65^{\circ} \mathrm{C}$ heating blocks

Disposable scalpel

Transilluminator

Magnetic stand

Shaking platform

\section{Prepare beads before the main procedure Oligo d(T) $)_{25}$ Magnetic Beads preparation}

1. Equilibrate the Oligo $d(\mathrm{~T})_{25}$ Magnetic Beads to room temperature (RT) for $20 \mathrm{~min}$ prior to use.

2. Wash $100 \mu$ of bead slurry with $500 \mu \mathrm{l}$ of $1 \mathrm{X}$ Annealing buffer in a $1.5 \mathrm{ml}$ microcentrifuge tube (per RNA sample). Collect the beads on a magnetic stand and discard the supernatant.

Note: if bead slurry for multiple samples is prepared in a $1.5 \mathrm{ml}$ microcentrifuge tube, use $1000 \mu \mathrm{l}$ of $1 \mathrm{X}$ Annealing buffer Beads for each wash. Repeat the wash once.

Curr Protoc Mol Biol. Author manuscript; available in PMC 2016 April 01. 
3. Resuspend the washed beads in $200 \mu \mathrm{l}$ of $1 \mathrm{X}$ Annealing buffer per RNA sample.

\section{Biotin- $\mathrm{T}_{45} \mathrm{U}_{5}$ oligo-coupled Dynabeads MyOne Streptavidin C1 preparation}

$4 \quad$ Wash $20 \mu \mathrm{l}$ of Dynabeads MyOne Streptavidin C1 slurry for each RNA sample with $100 \mu$ of Beads pre-wash buffer in a $1.5 \mathrm{ml}$ microcentrifuge tube. Collect the beads on a magnetic stand and discard the supernatant. Repeat the wash once.

Note: if Dynabeads slurry for multiple samples (up to 7 samples) is prepared in a $1.5 \mathrm{ml}$ microcentrifuge tube, use $1000 \mu \mathrm{l}$ of Beads prewash buffer for each wash.

$5 \quad$ Wash the beads with $100 \mu$ of $1 \mathrm{X}$ coupling buffer. Collect the beads on a magnetic stand and discard the supernatant. Repeat the wash once.

Note: if Dynabeads slurry for multiple samples is prepared in a $1.5 \mathrm{ml}$ microcentrifuge tube, use $1000 \mu \mathrm{l}$ of $1 \mathrm{X}$ coupling buffer for each wash.

6 Add the following to the washed beads (per RNA sample) and incubate for 30 min at RT with gentle shaking. Collect the beads on a magnetic stand and discard the supernatant.

- $\quad 1 \mu \mathrm{l}$ of $100 \mu \mathrm{M}$ Biotin- $\mathrm{T}_{45} \mathrm{U}_{5}$ oligo

- $\quad 99 \mu \mathrm{l}$ of nuclease-free $\mathrm{H}_{2} \mathrm{O}$

- $\quad 100 \mu \mathrm{l}$ of $2 \mathrm{X}$ Coupling buffer

Note: It can be scaled appropriately for the desired number of samples.

$7 \quad$ Wash the beads with $500 \mu \mathrm{l}$ of $1 \mathrm{X}$ Hybridization buffer. Collect the beads on a magnetic stand and discard the supernatant. Repeat the wash twice.

Note: if Dynabeads slurry for multiple samples is prepared in a $1.5 \mathrm{ml}$ microcentrifuge tube, use $1000 \mu \mathrm{l}$ of $1 \mathrm{X}$ Hybridization buffer for each wash.

8 Resuspend the washed beads in $100 \mu \mathrm{l}$ of $2 \mathrm{X}$ Hybridization buffer per RNA sample.

Note: Biotin- $\mathrm{T}_{45} \mathrm{U}_{5}$ oligo-coupled Dynabeads MyOne Streptavidin $\mathrm{C} 1$ can be prepared ahead of time and are stable for up to 2 months at $4^{\circ} \mathrm{C}$.

\section{Main Procedure}

\section{Isolate 3' end RNA fragments containing poly(A) sites}

$9 \quad$ Dilute $25 \mu \mathrm{g}$ of high quality total RNA with $100 \mu \mathrm{l}$ of nuclease-free $\mathrm{H}_{2} \mathrm{O}$ in a 1.5 $\mathrm{ml}$ microcentrifuge tube before adding $100 \mu \mathrm{l}$ of $2 \mathrm{X}$ Annealing buffer.

Note: RNA can be prepared by either a Hot-phenol extraction method or a TRIzol extraction method followed by purification using RNeasy Kit (Qiagen), including DNase I digestion, according to the 
manufacturer's instructions. The quality of RNA should be checked by electrophoresis or Agilent Bioanalyzer analysis (RNA 6000 Pico Kit).

10 Denature RNA sample from step 9 for $5 \mathrm{~min}$ at $65^{\circ} \mathrm{C}$ and then immediately cool on ice.

11 Pulse-spin the sample tube and mix the $200 \mu$ of denatured RNA sample with $200 \mu \mathrm{l}$ of washed Oligo d(T) $)_{25}$ Magnetic Beads from step 3. Incubate the tube for $30 \mathrm{~min}$ at RT with gentle shaking. Collect the beads on a magnetic stand and discard the supernatant.

12 Wash the beads with $200 \mu \mathrm{l}$ of $1 \mathrm{X}$ Annealing buffer. Collect the beads on a magnetic stand and discard the supernatant. Repeat the wash twice.

13 Wash beads once in $50 \mu \mathrm{l}$ of RNase III digestion buffer. Collect the beads on a magnetic stand and discard the supernatant.

14 Resuspend the RNA-bound beads in $50 \mu \mathrm{l}$ of RNase III digestion buffer with 2.5 U of RNase III (add $2.5 \mu \mathrm{l}$ of $1 \mathrm{U} / \mu \mathrm{l}$ RNase III to $47.5 \mu \mathrm{l}$ of RNase III digestion buffer). Incubate for $15 \mathrm{~min}$ at $37^{\circ} \mathrm{C}$. Collect the beads on a magnetic stand and discard the supernatant.

15 Wash beads with $200 \mu \mathrm{l}$ of $1 \mathrm{X}$ Annealing buffer. Collect the beads on a magnetic stand and discard the supernatant. Repeat the wash once.

16 Add $200 \mu \mathrm{l}$ of TE buffer and gently resuspend the beads by pipetting. Incubate for $2 \mathrm{~min}$ at $55^{\circ} \mathrm{C}$. Collect the beads on a magnetic stand and transfer the supernatant to a new $1.5-\mathrm{ml}$ microcentrifuge tube.

17 Add $200 \mu \mathrm{l}$ of acid phenol-chloroform and mix well. Centrifuge at 20,000 x $g$ for $5 \mathrm{~min}$ at RT and carefully transfer $190 \mu \mathrm{l}$ of the upper aqueous phase to a new $1.5-\mathrm{ml}$ microcentrifuge tube.

18 Add $19 \mu \mathrm{l}$ of $3 \mathrm{M}$ sodium acetate and $1 \mu \mathrm{l}$ of $15 \mathrm{mg} / \mathrm{ml}$ GlycoBlue to the purified RNA sample. Mix well. Add $475 \mu \mathrm{l}$ of $100 \%$ ethanol, mix well, and incubate for at least $30 \mathrm{~min}$ at $-20^{\circ} \mathrm{C}$.

19 Centrifuge at $20,000 \times g$ for $30 \mathrm{~min}$ at $4^{\circ} \mathrm{C}$, to precipitate RNA.

20 Discard the supernatant and gently wash the pellet with $500 \mu$ of $80 \%$ ice-cold ethanol. Centrifuge at $20,000 \times g$ for $5 \mathrm{~min}$ at $4{ }^{\circ} \mathrm{C}$. Discard all the supernatant carefully without disturbing the pellet.

21 Air-dry the pellet for $10 \mathrm{~min}$ at RT. Resuspend the air-dried RNA in $100 \mu \mathrm{l}$ of nuclease-free $\mathrm{H}_{2} \mathrm{O}$.

Note: the size of purified RNA fragments is generally smaller than $1000 \mathrm{nt}$, and the majority should be around $100-300 \mathrm{nt}$. The size distribution of the RNA fragments can be examined by Agilent Bioanalyzer analysis (RNA 6000 Pico Kit). The RNA sample can be stored for up to 3 months at $-80^{\circ} \mathrm{C}$. 
22 Denature RNA sample from step 21 for $5 \mathrm{~min}$ at $65^{\circ} \mathrm{C}$ and then immediately cool on ice.

23 Pulse-spin the sample tube and mix $100 \mu$ of denatured RNA sample with 100 $\mu \mathrm{l}$ of prepared Biotin- $\mathrm{T}_{45} \mathrm{U}_{5}$ oligo-coupled Dynabeads MyOne Streptavidin C1 from step 8. Incubate for 30 min at RT with gentle shaking. Collect the beads on a magnetic stand and discard the supernatant.

24 Wash the beads with $500 \mu$ l of High-stringency wash buffer. Collect the beads on a magnetic stand and discard the supernatant. Repeat the wash twice.

25 Wash the beads with $100 \mu \mathrm{l}$ of RNase $\mathrm{H}$ digestion buffer. Collect the beads on a magnetic stand and discard the supernatant.

26 Gently resuspend the beads in $50 \mu \mathrm{l}$ of RNase $\mathrm{H}$ digestion buffer with $5 \mathrm{U}$ of RNase H (add $1 \mu \mathrm{l}$ of $5 \mathrm{U} / \mu \mathrm{l}$ RNase $\mathrm{H}$ to $49 \mu \mathrm{l}$ RNase $\mathrm{H}$ digestion buffer). Incubate for $30 \mathrm{~min}$ at $37^{\circ} \mathrm{C}$. Collect the beads on a magnetic stand and transfer the supernatant to a new $1.5-\mathrm{ml}$ microcentrifuge tube.

27 Collect any residual RNA by washing the beads with $150 \mu$ of Elution buffer. Separate the beads on a magnetic stand and combine this supernatant with the one from step 26 . The total collected volume should be $200 \mu \mathrm{l}$.

28 Add $200 \mu \mathrm{l}$ of acid phenol-chloroform and mix well. Centrifuge at $20,000 \times g$ for $5 \mathrm{~min}$ at RT and carefully transfer $190 \mu \mathrm{l}$ of the upper aqueous phase to a new $1.5-\mathrm{ml}$ microcentrifuge tube.

29 Add $19 \mu \mathrm{l}$ of $3 \mathrm{M}$ sodium acetate and $1 \mu \mathrm{l}$ of $15 \mathrm{mg} / \mathrm{ml}$ GlycoBlue to the purified RNA sample. Mix well. Add $475 \mu$ of $100 \%$ ethanol, mix well, and incubate for at least $30 \mathrm{~min}$ at $-20^{\circ} \mathrm{C}$.

30 Centrifuge at $20,000 \times g$ for $30 \mathrm{~min}$ at $4^{\circ} \mathrm{C}$, to precipitate RNA.

31 Discard the supernatant and gently wash the pellet with $500 \mu \mathrm{l}$ of $80 \%$ ice-cold ethanol. Centrifuge at $20,000 \times g$ for $5 \mathrm{~min}$ at $4^{\circ} \mathrm{C}$. Discard all the supernatant carefully without disturbing the pellet.

32 Air-dry the pellet thoroughly for $10-20 \mathrm{~min}$ at RT. Resuspend the air-dried RNA in $7 \mu \mathrm{l}$ of nuclease-free $\mathrm{H}_{2} \mathrm{O}$.

Note: the quality and quantity of RNA fragments can be examined by Agilent Bioanalyzer analysis (RNA 6000 Pico Kit). The size distribution is similar to that seen in the RNA samples from step 21. The RNA sample can be stored for up to 3 months at $-80^{\circ} \mathrm{C}$.

\section{Ligate linkers to RNA fragments and perform reverse transcription}

Note: use a thermal cycler for all incubations

33 Transfer $6 \mu \mathrm{l}$ of RNA from step 32 to a new 0.5 -ml thin-walled PCR tube. Add 1 $\mu \mathrm{l}$ of $1 \mu \mathrm{M}$ Adapter A (3' DNA adapter) and mix by pipetting. Denature for 2 $\min$ at $70^{\circ} \mathrm{C}$ and then immediately cool on ice. 
34 Prepare the following ligation reaction master mix (per RNA sample) in a separate tube on ice and mix by pipetting.

- $\quad 1.5 \mu \mathrm{l}$ of 10X T4 RNA ligase buffer (supplied with T4 RNA ligase 2, $\mathrm{NEB})$

- $\quad 1 \mu \mathrm{l}$ of $20 \mathrm{U} / \mu \mathrm{l}$ SUPERase.In

- $\quad 4.5 \mu \mathrm{l}$ of $50 \%$ PEG8000 (supplied with T4 RNA ligase 2, NEB)

Note: It can be scaled appropriately for the desired number of samples. Dispense PEG8000 with a wide-bore tip to improve accuracy.

35 Add $7 \mu \mathrm{l}$ of the reaction master mix from step 34 to the denatured sample from step 33. Add $1 \mu \mathrm{l}$ of $200 \mathrm{U} / \mu \mathrm{l}$ truncated T4 RNA ligase 2 and mix by pipetting. Incubate for $2 \mathrm{hr}$ at $25^{\circ} \mathrm{C}$.

36 Add $1 \mu \mathrm{l}$ of $5 \mu \mathrm{M}$ Primer B (RT-PCR primer) to the ligation mix and mix by pipetting. Incubate the sample for $2 \mathrm{~min}$ at $70^{\circ} \mathrm{C}$, then for $5 \mathrm{~min}$ at $37^{\circ} \mathrm{C}$, followed by a cool down to $4^{\circ} \mathrm{C}$.

37 Prepare $5 \mu \mathrm{l}$ of $5 \mu \mathrm{M}$ Adapter C (5' RNA adapter) in a new 0.5-ml thin-walled PCR tube. Denature for $2 \mathrm{~min}$ at $70^{\circ} \mathrm{C}$ and then immediately cool on ice.

Note: $1 \mu \mathrm{l}$ of Adapter $\mathrm{C}$ is needed for each RNA sample. We prefer to denature a larger volume of Adapter C (e.g., 5 - $10 \mu \mathrm{l})$ to avoid potential volume loss in denaturation process.

38 Prepare the following ligation reaction master mix (per RNA sample) in a separate tube on ice and mix by pipetting.

- $\quad 0.5 \mu \mathrm{l}$ of 10X T4 RNA ligase buffer (supplied with T4 RNA ligase 1, NEB)

- $\quad 1 \mu \mathrm{l}$ of denatured Adapter C from step 37

- $\quad 1.5 \mu \mathrm{l}$ of $10 \mathrm{mM}$ ATP (supplied with T4 RNA ligase $1, \mathrm{NEB}$ )

Note: It can be scaled appropriately for the desired number of samples.

39 Add $3 \mu \mathrm{l}$ of the reaction master mix from step 38 to the sample from step 36. Add $1 \mu \mathrm{l}$ of $10 \mathrm{U} / \mu \mathrm{l} \mathrm{T} 4 \mathrm{RNA}$ ligase 1 and mix by pipetting. Incubate for $1.5 \mathrm{hr}$ at $25^{\circ} \mathrm{C}$.

$40 \quad$ Add $7 \mu$ of $5 X$ First-Strand buffer (supplied with SuperScript III RT, Invitrogen) to the sample from step 39 . Incubate for $5 \mathrm{~min}$ at $70^{\circ} \mathrm{C}$ and then immediately cool on ice.

41 Prepare the following reverse transcription reaction master mix (per RNA sample) in a separate tube on ice and mix by pipetting.

- $\quad 1.75 \mu \mathrm{l}$ of $12.5 \mathrm{mM}$ dNTPs 
- $\quad 3.5 \mu \mathrm{l}$ of $100 \mathrm{mM}$ DTT (supplied with SuperScript III RT, Invitrogen)

- $1 \mu \mathrm{l}$ of $20 \mathrm{U} / \mu \mathrm{l}$ SUPERase.In

- $\quad 0.75 \mu$ l of nuclease-free $\mathrm{H}_{2} \mathrm{O}$

Note: It can be scaled appropriately for the desired number of samples.

$42 \quad$ Add $7 \mu$ of the reaction master mix from step 41 to the mixture from step 40. Add $1 \mu \mathrm{l}$ of $200 \mathrm{U} / \mu \mathrm{l}$ SuperScript III reverse transcriptase and mix by pipetting. Incubate for $60 \mathrm{~min}$ at $50^{\circ} \mathrm{C}$, then for $15 \mathrm{~min}$ at $70^{\circ} \mathrm{C}$, followed by a cool down to $4^{\circ} \mathrm{C}$.

Note: If not proceeding immediately, the cDNA sample can be stored indefinitely at $-20^{\circ} \mathrm{C}$.

\section{PCR amplify DNA library for sequencing}

43 Prepare the following PCR reaction master mix (per cDNA sample) for amplification in a separate tube on ice and mix by pipetting.

- $10 \mu \mathrm{l}$ of $5 \mathrm{X}$ HF buffer (supplied with Phusion HF DNA polymerase, NEB)

- $\quad 0.5 \mu \mathrm{l}$ of $25 \mathrm{mM}$ dNTPs

- $\quad 1 \mu \mathrm{l}$ of $25 \mu \mathrm{M}$ Universal primer

- $\quad 19.5 \mu \mathrm{l}$ of nuclease-free $\mathrm{H}_{2} \mathrm{O}$

Note: It can be scaled appropriately for the desired number of samples.

44 Transfer $17.5 \mu \mathrm{l}$ of cDNA sample from step 42 to a new 0.5 -ml thin-walled PCR tube. Add $1 \mu$ of $25 \mu \mathrm{M}$ desired Index primer and mix by pipetting.

$45 \quad$ Add $31 \mu \mathrm{l}$ of PCR reaction master mix from step 43 to the mixture from step 44. Add $0.5 \mu \mathrm{l}$ of $2 \mathrm{U} / \mu \mathrm{l}$ Phusion HF DNA polymerase and mix by pipetting.

46 Perform PCR as follows:

- $\quad 98^{\circ} \mathrm{C}$ for $30 \mathrm{sec}$

- 16 cycles of $98^{\circ} \mathrm{C}$ for $30 \mathrm{sec}, 60^{\circ} \mathrm{C}$ for $30 \mathrm{sec}, 72^{\circ} \mathrm{C}$ for $30 \mathrm{sec}$

- $72^{\circ} \mathrm{C}$ for $10 \mathrm{~min}$

- $\quad 4^{\circ} \mathrm{C}$ hold

Note: Higher yield of DNA library can be achieved through increasing the number of PCR amplification cycles up to 18 cycles. Generally we don't find PCR reactions in this condition (16 - 18 cycles) to be saturated or to produce any spurious high molecular weight PCR products. 


\section{Purify amplified DNA library using DNA SizeSelector-I SPRI magnetic beads}

47 Equilibrate the DNA SizeSelector-I SPRI magnetic beads to RT for $20 \mathrm{~min}$.

48 Transfer the DNA library from step 46 to a new $1.5-\mathrm{ml}$ microcentrifuge tube. Add nuclease-free $\mathrm{H}_{2} \mathrm{O}$ to adjust the final volume to $100 \mu \mathrm{l}$.

49 Add $200 \mu \mathrm{l}$ of thoroughly-vortexed SPRI bead slurry to the DNA sample from step 48 and mix by pipetting.

Note: The recommended 2:1 volume ratio of SPRI bead slurry to DNA sample is specific for preferentially purifying DNA fragment larger than $200 \mathrm{bp}$ (see explanation in step 54). The ratio should be empirically determined for every batch of SPRI beads using DNA size ladder as a reference (e.g., 100 bp DNA Ladder). Precise volumes of bead slurry and DNA sample are critical because even small ratio variations can significantly alter the size range of the DNA fragments retained by the SPRI beads. In order to minimize pipetting variation, we prefer to increase the DNA sample volume to $100 \mathrm{ul}$.

50 Incubate the mixture for 5 min at RT. Collect the beads on a magnetic stand and carefully discard the supernatant.

51 Wash the beads with $200 \mu \mathrm{l}$ of $70 \%$ ethanol. Collect the beads on a magnetic stand and discard the supernatant. Repeat the wash once.

52 Air-dry the beads on a magnetic stand for $10 \mathrm{~min}$ or until the beads are completely dry.

Note: The dried patch of beads will show small "cracks" and other irregularities that are visible with careful inspection.

53 Resuspend the dried beads in $22 \mu$ of $10 \mathrm{mM}$ Tris-Cl, $\mathrm{pH}$ 8. Collect the beads on a magnetic stand. Taking great care to avoid any carry-over of beads, transfer only $20 \mu \mathrm{l}$ of the supernatant to a new $1.5-\mathrm{ml}$ microcentrifuge tube.

Note: the DNA library can be stored indefinitely at $-20^{\circ} \mathrm{C}$.

\section{Evaluate DNA sequencing library}

54 Examine the quality and concentration of the purified DNA library using Agilent Bioanalyzer analysis (High-sensitivity DNA Kit).

Note: A typical result from Agilent Bioanalyzer analysis is shown in Figure 2A. The concentration of the DNA library is calculated using only those DNA fragments with sizes ranging from 175 - $500 \mathrm{bp}$. A small amount of DNA smaller than 175 bp will remain in SPRI-beadspurified samples. This includes library DNAs with very short cDNA inserts (which are poor candidates for unique mapping to a reference genome), PCR primer dimers, and residual PCR primers. Gel purification is required to further extract DNA fragments with sizes only in the desired $175-500$ bp range. If multiple uniquely indexed 
DNA libraries are planned to be sequenced in a single multiplexed sequencing run, the DNA libraries can be pooled according to the desired molar ratio at this stage before further gel purification. In determining the molar ratio, consider only the concentration of DNA fragments in the $175-500 \mathrm{bp}$ range for each sample.

\section{Purify the DNA sequencing library}

55 Add an appropriate amount of 6X Gel Loading Dye to the DNA library and load the mixture to an $8 \%$ TBE polyacrylamide gel. Run at $180 \mathrm{~V}$ for $40 \mathrm{~min}$.

56 Stain gel with SYBR Gold (1:10,000 dilution) in $30 \mathrm{ml}$ TBE buffer for $3 \mathrm{~min}$ at RT with gentle shaking.

57 Excise DNA fragments in the $175-500$ bp range with a disposable scalpel on a transilluminator.

Note: avoid inclusion of any smaller DNA fragments.

58 Transfer the excised gel piece to a $0.5-\mathrm{ml}$ thin-walled PCR tube with the bottom pierced through by a 20 -gauge needle. Nest the $0.5-\mathrm{ml}$ PCR tube on top of a new $1.5-\mathrm{ml}$ microcentrifuge tube.

59 Centrifuge the nested tubes at $20,000 \times g$ for $3 \mathrm{~min}$ at RT, to effectively pulverize the relatively large gel piece into smaller pieces by squeezing the gel through the hole in the pierced tube.

60 Add $400 \mu \mathrm{l}$ of Gel extraction buffer to resuspend the pulverized gel pieces. Incubate overnight at RT with agitation.

61 Transfer the whole gel/buffer mixture to the filter chamber of a Costar Spin-X centrifuge tube. Centrifuge at $20,000 \times g$ for $2 \mathrm{~min}$ at RT.

62 Transfer $400 \mu \mathrm{l}$ of the eluate from the collection tube to a new $1.5-\mathrm{ml}$ microcentrifuge tube. Add $1 \mu \mathrm{l}$ of $15 \mathrm{mg} / \mathrm{ml}$ GlycoBlue to the eluted DNA sample and mix well. Add $1000 \mu \mathrm{l}$ of $100 \%$ ethanol, mix well, and incubate for at least $30 \mathrm{~min}$ at $-20^{\circ} \mathrm{C}$.

63 Centrifuge at $20,000 \times g$ for $30 \mathrm{~min}$ at $4^{\circ} \mathrm{C}$, to precipitate DNA.

64 Discard the supernatant and gently wash the pellet with $750 \mu \mathrm{l}$ of $80 \%$ ice-cold ethanol. Centrifuge at $20,000 \times g$ for $5 \mathrm{~min}$ at $4^{\circ} \mathrm{C}$. Discard all the supernatant carefully without disturbing the pellet.

65 Air-dry the pellet for $10 \mathrm{~min}$. Resuspend the air-dried DNA in $15 \mu \mathrm{l}$ of $10 \mathrm{mM}$ Tris-Cl, $\mathrm{pH} 8$.

Note: the DNA sequencing library can be stored indefinitely at $-20^{\circ} \mathrm{C}$. The quality and concentration of the gel-purified DNA library can be examined by Agilent Bioanalyzer analysis (High-sensitivity DNA Kit). The DNA library can be readily processed on Illumina HiSeq sequencing platform for single-end sequencing using the sequencing 
and index sequencing primers listed in Table 1 (Both primers are those standardly used in Illumina TruSeq Small RNA sequencing runs).

\section{SUPPORT PROTOCOL}

\section{Sequencing data analysis}

The protocol here briefly describes how the raw sequencing data can be processed to identify poly(A) sites (Figure 3) and also describes typical downstream analyses.

\section{Identify poly(A) site supporting (PASS) reads}

1. Trim the first four nucleotides (corresponding to four random nucleotides from Adapter A) and consecutive Ts from 5' end of sequence reads. Record the four nucleotides and number of Ts trimmed for later PASS reads identification. Also trim any sequences from the 3' end of sequence reads corresponding to Adapter C.

Note: the antisense strand of the DNA library is sequenced.

2. Align the trimmed reads to reference transcriptome sequences and genomic sequences. (e.g., using Tophat command tophat $-p 2-G \ldots$.)

3. Select uniquely aligned reads and compare previously trimmed $\mathrm{T}$ stretches from each read to 3' end genomic sequences immediately after where that read is aligned. Reads with at least two Ts not matched with genomic sequence are considered as PASS reads. The last aligned position is considered the poly(A) site.

Note: When 3' end of an aligned region has encoded consecutive Ts in its genomic sequence, it is impossible to determine the true poly(A) site. Arbitrarily, the poly(A) site is assigned to the last aligned non-T nucleotide. Reads with only one non-genomically encoded $\mathrm{T}$ can also be used for Poly(A) identification, if desired.

\section{Cluster poly(A) sites (optional)}

Note: For certain analyses, poly(A) sites located in a small window are typically clustered and treated as one representative poly(A) site. Here is one way to cluster poly(A) sites.

Cluster defined poly(A) sites based on PASS reads within $24 \mathrm{nt}$ from each other. If a cluster size is $\underline{2} 4 \mathrm{nt}$, the site with the highest number of PASS reads is assigned as the representative poly(A) site. If a cluster size is $>24 \mathrm{nt}$, the representative poly(A) site with the highest number of PASS reads in the cluster is assigned and PASS reads located $>24 \mathrm{nt}$ from the assigned representative poly(A) site is re-clustered. Repeat this process until all representative poly(A) sites in clusters are defined.

Note: One way to increase the stringency of the poly(A) site identification and reduce false positives is to require that a poly(A) site be supported by at least two distinct PASS reads (based on a different number of nongenomic Ts and/or a different set of four nucleotides at the 5' end of a read resulting from random nucleotides in Adapter A). Another method is to require that the number of PASS reads used to define a poly(A) site be $25 \%$ of all PASS reads for that particular gene. 


\section{Calculate gene expression levels and usage of alternative poly(A) sites}

The gene expression level is calculated as the total number of PASS reads assigned to a gene (located in exons, introns, and 3' UTRs), normalized to the total PASS reads in a dataset. Non-PASS reads (reads with no non-genomic Ts at the 5' end) can also be included for gene expression analysis when comparing different datasets. However, it is not recommended to include non-PASS reads when comparing expression levels of different genes in the same dataset, because the number of non-PASS reads is correlated with A-richness of mRNA sequences.

A poly(A) site usage level is estimated as the ratio of number of PASS reads assigned to a particular poly(A) site and total number of PASS reads belonging to the gene.

\section{REAGENTS AND SOLUTIONS}

Use deionized, distilled water in all recipes and protocol steps. For common stock solutions, see APPENDIX 2; for suppliers, see APPENDIX 4.

\section{Beads pre-wash buffer $(100 \mathrm{ml})$}

$1 \mathrm{ml} 10 \mathrm{M} \mathrm{NaOH}$ (100 mM final; APPENDIX 2)

$1 \mathrm{ml} 5 \mathrm{M} \mathrm{NaCl}(50 \mathrm{mM}$ final; APPENDIX 2)

$50 \mu \mathrm{l}$ TWEEN 20 (0.05\% final)

Add up to $100 \mathrm{ml}$ with nuclease-free $\mathrm{H}_{2} \mathrm{O}$

Store indefinitely at RT

\section{X Annealing buffer $(100 \mathrm{ml})$}

$2 \mathrm{ml} 1 \mathrm{M}$ Tris-Cl, pH7.5 (20 mM final; APPENDIX 2)

$2.4 \mathrm{ml} 5 \mathrm{M} \mathrm{NaCl}$ (120 mM final; APPENDIX 2)

$400 \mu l 0.5$ M EDTA (2 mM final; APPENDIX 2)

Add up to $100 \mathrm{ml}$ with nuclease-free $\mathrm{H}_{2} \mathrm{O}$

Store indefinitely at RT

\section{X Coupling buffer $(100 \mathrm{ml})$}

$2 \mathrm{ml} 1 \mathrm{M}$ Tris-Cl, pH7.5 (20 mM final; APPENDIX 2)

$40 \mathrm{ml} 5 \mathrm{M} \mathrm{NaCl}$ (2 M final; APPENDIX 2)

$400 \mu \mathrm{l} 0.5$ M EDTA (2 mM final; APPENDIX 2)

$100 \mu \mathrm{l}$ TWEEN 20 (0.1\% final)

Curr Protoc Mol Biol. Author manuscript; available in PMC 2016 April 01. 
Add up to $100 \mathrm{ml}$ with nuclease-free $\mathrm{H}_{2} \mathrm{O}$

Store indefinitely at RT

2X Hybridization buffer (100 ml)

$2 \mathrm{ml} 1 \mathrm{M}$ Tris-Cl, pH7.5 (20 mM final; APPENDIX 2)

$6 \mathrm{ml} 5 \mathrm{M} \mathrm{NaCl}$ (300 mM final; APPENDIX 2)

$400 \mu 10.5$ M EDTA (2 mM final; APPENDIX 2)

$100 \mu \mathrm{l}$ TWEEN 20 (0.1\% final)

Add up to $100 \mathrm{ml}$ with nuclease-free $\mathrm{H}_{2} \mathrm{O}$

Store indefinitely at RT

High-stringency wash buffer $(100 \mathrm{ml})$

$1 \mathrm{ml} 1 \mathrm{M}$ Tris-Cl, pH7.5 (10 mM final; APPENDIX 2)

$20 \mu \mathrm{l} 5 \mathrm{M} \mathrm{NaCl}$ (1 mM final; APPENDIX 2)

$200 \mu \mathrm{l}$ 0.5 M EDTA (1 mM final; APPENDIX 2)

$50 \mu \mathrm{l}$ TWEEN 20 (0.05\% final)

$10 \mathrm{ml}$ Formamide (10\% final)

Add up to $100 \mathrm{ml}$ with nuclease-free $\mathrm{H}_{2} \mathrm{O}$

Store for up to 1 year at $4^{\circ} \mathrm{C}$

RNase III digestion buffer $(100 \mathrm{ml})$

$1 \mathrm{ml} 1 \mathrm{M}$ Tris-Cl, pH8.3 (10 mM final; APPENDIX 2)

$1.2 \mathrm{ml} 5 \mathrm{M} \mathrm{NaCl}$ (60 mM final; APPENDIX 2)

$1 \mathrm{ml} 1 \mathrm{M} \mathrm{MgCl}_{2}$ (10 mM final; APPENDIX 2)

$100 \mu \mathrm{l} 1 \mathrm{M}$ DTT (1 mM final; APPENDIX 2)

Add up to $100 \mathrm{ml}$ with nuclease-free $\mathrm{H}_{2} \mathrm{O}$

Store in small aliquots for up to 2 years at $-20^{\circ} \mathrm{C}$

\section{RNase $\mathrm{H}$ digestion buffer $(100 \mathrm{ml})$}

$5 \mathrm{ml} 1 \mathrm{M}$ Tris-Cl, pH8.3 (50 mM final; APPENDIX 2)

$20 \mu \mathrm{l} 5 \mathrm{M} \mathrm{NaCl}(1 \mathrm{mM}$ final; APPENDIX 2) 
$300 \mu \mathrm{l} 1 \mathrm{M} \mathrm{MgCl}_{2}$ (3 mM final; APPENDIX 2)

$1 \mathrm{ml} 1 \mathrm{M}$ DTT (10 mM final; APPENDIX 2)

Add up to $100 \mathrm{ml}$ with nuclease-free $\mathrm{H}_{2} \mathrm{O}$

Store in small aliquots for up to 2 years at $-20^{\circ} \mathrm{C}$

\section{Elution buffer $(100 \mathrm{ml})$}

$20 \mu 15 \mathrm{M} \mathrm{NaCl}$ (1 mM final; APPENDIX 2)

$200 \mu 10.5$ M EDTA (1 mM final; APPENDIX 2)

$50 \mu \mathrm{l}$ TWEEN 20 (0.05\% final)

Add up to $100 \mathrm{ml}$ with nuclease-free $\mathrm{H}_{2} \mathrm{O}$

Store indefinitely at RT

TE buffer (100 ml)

$1 \mathrm{ml} 1 \mathrm{M}$ Tris-Cl, pH7.5 (10 mM final; APPENDIX 2)

$200 \mu \mathrm{l}$ 0.5 M EDTA (1 mM final; APPENDIX 2)

Add up to $100 \mathrm{ml}$ with nuclease-free $\mathrm{H}_{2} \mathrm{O}$

Store indefinitely at RT

\section{Gel extraction buffer $(100 \mathrm{ml})$}

$1 \mathrm{ml} 1 \mathrm{M}$ Tris-Cl, pH8 (10 mM final; APPENDIX 2)

$6 \mathrm{ml} 5 \mathrm{M} \mathrm{NaCl}$ (300 mM final; APPENDIX 2)

$200 \mu \mathrm{l} 0.5$ M EDTA (1 mM final; APPENDIX 2)

Add up to $100 \mathrm{ml}$ with nuclease-free $\mathrm{H}_{2} \mathrm{O}$

Store indefinitely at RT

\section{COMMENTARY}

\section{Background Information}

Poly(A) tails at the ends of most mRNAs (and some noncoding RNAs) in eukaryotic organisms are typically generated through a cleavage and polyadenylation process on nascent RNAs (Colgan and Manley, 1997). Cis-elements and trans-factors work in concert to mediate poly(A) site selection (Mandel et al., 2008; Moqtaderi et al., 2013; Proudfoot and O'Sullivan, 2002; Proudfoot, 2011). Most eukaryotic genes are transcribed into mRNAs with alternative poly(A) sites (Tian and Manley, 2013). mRNA isoforms generated through alternative poly(A) sites have different 3' UTRs, where many cis-elements reside for gene 
expression regulation (Di Giammartino et al., 2011). Previous studies have shown that mRNA isoforms might have important biological roles in a variety of processes, such as development (Ji et al., 2009; Mangone et al., 2010; Thomsen et al., 2010), cell proliferation (Sandberg et al., 2008), and cancer cell transformation (Mayr and Bartel, 2009; Singh et al., 2009).

In order to better understand the potential functions of mRNA isoforms, precise identification of all poly(A) sites on a genomic scale is of critical importance. In recent years, a number of strategies utilizing high-throughput sequencing have been proposed to identify poly(A) sites in a genome-wide manner. One popular approach is to initiate cDNA synthesis from the 3' end of polyadenylated RNAs by using an oligo-dT primer or variant thereof (e.g., oligo-(dT) $)_{20}$ followed by two locking bases, a non-T nucleotide, then a random nucleotide), followed by library construction (Derti et al., 2012; Fox-Walsh et al., 2011; Shepard et al., 2011; Yoon and Brem, 2010). One obvious shortcoming of the oligo-dT based methods is that a significant fraction of the resulting sequence reads reflect internal priming from A-rich regions in the genome, which presents the challenge of distinguishing true poly(A) sites from internal priming sites.

Another oligo-dT based method is direct RNA sequencing using the Helicos single molecule sequencing technology (Ozsolak et al., 2010; Ozsolak et al., 2009). In this method, the poly(A) tail of an individual RNA is annealed to an immobilized oligo-dT primer for direct sequencing of the hybridized RNA without any additional manipulations or library construction steps. This approach largely avoids potential biases introduced by the various manipulations typically used in the generation of sequencing libraries and is particularly good at revealing less frequently utilized poly(A) sites. Unfortunately, the commercial availability of such sequencing technology is currently very limited.

The Poly(A)-position profiling by sequencing (3P-seq) method developed by the Bartel laboratory is a strategy to identify poly(A) sites independent of reverse transcription by using an oligo-dT primer (Jan et al., 2011). Through a splint-ligation of an oligonucleotide to the end of the poly(A) tail, 3P-seq captures poly(A) sites with immediate upstream RNA sequences and dramatically decreases non-specific sequence reads arising from internal priming at A-rich loci. While 3P-seq is a useful and creative method for genome-wide poly(A) identification, the protocol can be laborious, and it requires a high sequencing depth, because only a relatively small percentage of reads can be used for accurately identifying poly(A) sites.

The protocol described in this unit is modified from a recently published method named 3'READS (Hoque et al., 2013). The main advantages of 3'READS over previously proposed methods include: a) Significantly minimized internal priming artifacts relative to oligo-dT based reverse transcription; b) Reduction in sequence reads resulting from partially degraded RNAs with short oligo(A) tails, due to the stringency of the wash conditions (10\% formamide); c) Preservation of a few As from the poly(A) tail, a feature essential for poly(A) identification, thanks to the use of the hybrid Biotin- $\mathrm{T}_{45} \mathrm{U}_{5}$ oligo and RNase $\mathrm{H}$ digestion; d) A high percentage of sequence reads suitable for poly(A) identification; e) Quantitative analysis of gene expression and poly(A) site usage. 


\section{Critical Parameters and Troubleshooting}

RNA fragmentation by RNase III digestion-After RNase III digestion, it is important to examine the size distribution of the bound RNA fragments with poly(A) tails. An ideal digestion would result in most RNA fragments being in the range of $100-300 \mathrm{nt}$. Base on our experience, the proposed digestion conditions ( $2.5 \mathrm{U}$ of RNase III, 15 min digestion at $37^{\circ} \mathrm{C}$ ) works fairly well on RNA samples extracted from multiple human cell lines, mouse, and yeast species. However, it is worthwhile to empirically determine good digestion conditions for a particular RNA sample if a less ideal fragmentation pattern is observed using the proposed conditions.

\section{Removal of most of but not all poly(A) tail sequence by RNase $\mathrm{H}$ digestion-In} order to confidently identify poly(A) sites in the genome, one of the key steps in this protocol is the generation of RNA fragments that contain the poly(A) sites with a few As remaining from the poly(A) tails. Utilizing a special chimeric DNA/RNA oligonucleotide (Biotin- $\mathrm{T}_{45} \mathrm{U}_{5}$ ) in combination with appropriate digestion by RNase $\mathrm{H}$ (which specifically degrades the RNA in RNA/DNA hybrids), most, but not all, poly(A) tail sequence is removed (see Figure 2B for a typical distribution of the number of As from poly(A) tails left). Insufficient digestion by RNase $\mathrm{H}$ can leave RNA fragments with long poly(A) tails. Consequently, a large proportion of sequence reads would include a long stretch of Ts and the remaining sequence information might be insufficient for unique alignment to a reference genome. On the other hand, extreme over-digestion by RNase $\mathrm{H}$ can remove all poly(A) tail sequences despite the intended protection offered by the 5 uridines in the chimeric Biotin- $\mathrm{T}_{45} \mathrm{U}_{5}$ oligo. RNA fragments with no As left from poly(A) sequence are unable to be definitively identified as poly(A) sites. An excessive number of these fragments is indicative of over-digestion by RNase $\mathrm{H}$. In our hands, both $1 \mathrm{U}$ and $5 \mathrm{U}$ of RNase $\mathrm{H}$ for $30 \mathrm{~min}$ at $37^{\circ} \mathrm{C}$ offer appropriate digestion for a wide range of samples. To ensure adequate enzyme activity despite variation in different commercial lots, we prefer to use $5 \mathrm{U}$ of RNase H.

\section{Insertion of four random nucleotides in the end of adapters}

The strong sequence and structural biases in RNA ligase-mediated ssRNA/ssRNA ligation and ssRNA/ssDNA ligation can lead to distorted RNA profiles through in high-throughput sequencing results (Jayaprakash et al., 2011; Zhuang et al., 2012). In order to minimize the effects of the ligation biases of T4 RNA ligases in the sequencing library construction steps, four random nucleotides are added to the end of adapters used for ligation. Random nucleotides in adapters also contribute to higher ligation efficiency. Furthermore, overrepresentation of certain RNA fragments caused by any biases from the PCR amplification step in the library construction process can be accurately assessed by analyzing the distribution frequency of the first four nucleotides in selected sequence reads. Finally, the presence of four random nucleotides in Adapter A greatly help cluster-calling on the flow cells of the Illumina sequencing platform, because the Illumina cluster-calling algorithm expects a roughly equal base composition at any given position of the first few nucleotides. Overrepresentation of a stretch of Ts (the complementary reads resulting from the residual poly(A) tail As) would cause inefficient cluster-calling. 


\section{Addition of $\mathbf{0 . 0 5 \%}$ TWEEN 20 to buffers used with Dynabeads MyOne Streptavidin C1}

Dynabeads MyOne Streptavidin C1 tend to stick on to the walls of microcentrifuge tubes as well as pipette tips during washes, transfer, and incubation steps, which makes it challenging and time-consuming to fully recover the beads and bead-bound samples. Addition of a very low percentage of TWEEN 20 (0.05\% final) alleviates the difficulty in collecting and transferring Dynabeads due to stickiness, while not affecting the performance of the Dynabeads MyOne Streptavidin C1 in this protocol.

\section{Quantification of DNA sequencing library}

To examine the quality and quantity of the libraries, we prefer to use SPRI magnetic beads (DNA SizeSelector-I) to purify the PCR amplified DNA sequencing libraries prior to Agilent Bioanalyzer analysis (High-sensitivity DNA Kit). Bioanalyzer analysis allows for easy quantification of the concentration of DNA fragments in the useful range for sequencing $(175-500 \mathrm{bp})$ as well as a visual assessment of the levels of undesirable shortlength byproducts such as primer dimers and small (non-mappable) fragments. Based on the concentration of DNA fragments in the $175-500$ bp range, uniquely indexed DNA libraries can be combined according to the desired molar ratio prior to purification on $8 \%$ TBE polyacrylamide gels. Alternatively, SPRI magnetic beads can be used to further purify combined DNA libraries, in lieu of $8 \%$ TBE polyacrylamide gels. Based on our experience, it normally takes additional two rounds of purification by SPRI magnetic beads to completely remove DNA fragments smaller than $200 \mathrm{bp}$. While much faster than the gel purification, the drawback of performing two additional rounds of SPRI size selection is that a several-fold greater amount of initial material is required to offset the loss of material during the purification, in order to obtain a comparable amount of quality DNA libraries suitable for sequencing.

Alternatively, the PCR-amplified DNA sequencing library can be directly purified by electrophoresis on an $8 \%$ TBE polyacrylamide gel in order to extract DNA fragments in the range of $175-500 \mathrm{bp}$. One potential drawback is that it can be time consuming to gel purify each library individually if multiple libraries are planned to be combined for a single sequencing run. After purification by an $8 \%$ polyacrylamide gel, a DNA library can be quantified by Agilent Bioanalyzer analysis (High-sensitivity DNA Kit) as well as by Quantitative-PCR (Q-PCR) analysis by comparison to previously calibrated/sequenced DNA libraries using Q-PCR checking primers $F$ and $R$ (Table 1). In theory, quantification by Q-PCR leads to a more accurate estimation of the amount of DNA that can be effectively clustered on the surface of flow cell. In this case, one can better predict the number of expected reads for each DNA library in a multiplexed sequencing run.

\section{No or low DNA library content after PCR amplification}

As this is a relatively long protocol, there are many steps could contribute to no or low DNA library content after final amplification. However, in our opinion, it is always useful to check the activity of each enzyme used in the protocol before other troubleshooting, since a faulty enzyme is one of typical cause of failures. 


\section{Anticipated Results}

The concentration of a purified DNA library is normally $5-10 \mathrm{nM}$. For a typical sequencing run involving such libraries, $65-75 \%$ of the raw reads can be uniquely aligned to a reference genome, and $60-65 \%$ of the uniquely mapped reads can be used to identify poly(A) sites (only uniquely mapped reads containing at least 2 non-genomic Ts are considered for identification of poly(A) sites).

\section{Time Considerations}

This protocol can be completed over 3 - 4 days. Beads preparations and isolation of 3' end RNA fragments containing poly(A) sites can be done in 1 day. Library construction and purification take $2-3$ days. In this protocol, there are many steps at different stages (i.e., steps $18,21,29,32,42$, and 53) where the sample preparation can be temporarily stopped without adversely affecting the outcome. As such, the entire procedure can be performed over a fairly extended time period with considerable flexibility.

\section{Acknowledgments}

We thank all members of the Struhl laboratory for insightful discussions. This work was supported by grants to K.S. from the National Institutes of Health (GM 30186 and CA 107486).

\section{Literature Cited}

Colgan DF, Manley JL. Mechanism and regulation of mRNA polyadenylation. Genes \& development. 1997; 11:2755-2766. [PubMed: 9353246]

Derti A, Garrett-Engele P, Macisaac KD, Stevens RC, Sriram S, Chen R, Rohl CA, Johnson JM, Babak T. A quantitative atlas of polyadenylation in five mammals. Genome research. 2012; 22:1173-1183. [PubMed: 22454233]

Di Giammartino DC, Nishida K, Manley JL. Mechanisms and consequences of alternative polyadenylation. Mol Cell. 2011; 43:853-866. [PubMed: 21925375]

Elkon R, Ugalde AP, Agami R. Alternative cleavage and polyadenylation: extent, regulation and function. Nature reviews. Genetics. 2013; 14:496-506.

Fox-Walsh K, Davis-Turak J, Zhou Y, Li H, Fu XD. A multiplex RNA-seq strategy to profile poly(A +) RNA: application to analysis of transcription response and $3^{\prime}$ end formation. Genomics. 2011; 98:266-271. [PubMed: 21515359]

Geisberg JV, Moqtaderi Z, Fan X, Ozsolak F, Struhl K. Global analysis of mRNA isoform half-lives reveals stabilizing and destabilizing elements in yeast. Cell. 2014; 156:812-824. [PubMed: 24529382]

Hoque M, Ji Z, Zheng D, Luo W, Li W, You B, Park JY, Yehia G, Tian B. Analysis of alternative cleavage and polyadenylation by $3^{\prime}$ region extraction and deep sequencing. Nat Methods. 2013; 10:133-139. [PubMed: 23241633]

Hoque M, Li W, Tian B. Accurate mapping of cleavage and polyadenylation sites by $3^{\prime}$ region extraction and deep sequencing. Methods in molecular biology. 2014; 1125:119-129. [PubMed: 24590784]

Jan CH, Friedman RC, Ruby JG, Bartel DP. Formation, regulation and evolution of Caenorhabditis elegans 3'UTRs. Nature. 2011; 469:97-101. [PubMed: 21085120]

Jayaprakash AD, Jabado O, Brown BD, Sachidanandam R. Identification and remediation of biases in the activity of RNA ligases in small-RNA deep sequencing. Nucleic Acids Res. 2011; 39:e141. [PubMed: 21890899]

Ji Z, Lee JY, Pan Z, Jiang B, Tian B. Progressive lengthening of $3^{\prime}$ untranslated regions of mRNAs by alternative polyadenylation during mouse embryonic development. Proc Natl Acad Sci U S A. 2009; 106:7028-7033. [PubMed: 19372383] 
Mandel CR, Bai Y, Tong L. Protein factors in pre-mRNA 3'-end processing. Cellular and molecular life sciences : CMLS. 2008; 65:1099-1122. [PubMed: 18158581]

Mangone M, Manoharan AP, Thierry-Mieg D, Thierry-Mieg J, Han T, Mackowiak SD, Mis E, Zegar C, Gutwein MR, Khivansara V, et al. The landscape of C. elegans 3'UTRs. Science. 2010; 329:432-435. [PubMed: 20522740]

Mayr C, Bartel DP. Widespread shortening of 3'UTRs by alternative cleavage and polyadenylation activates oncogenes in cancer cells. Cell. 2009; 138:673-684. [PubMed: 19703394]

Moqtaderi Z, Geisberg JV, Jin Y, Fan X, Struhl K. Species-specific factors mediate extensive heterogeneity of mRNA 3' ends in yeasts. Proc Natl Acad Sci U S A. 2013; 110:11073-11078. [PubMed: 23776204]

Ozsolak F, Kapranov P, Foissac S, Kim SW, Fishilevich E, Monaghan AP, John B, Milos PM. Comprehensive polyadenylation site maps in yeast and human reveal pervasive alternative polyadenylation. Cell. 2010; 143:1018-1029. [PubMed: 21145465]

Ozsolak F, Platt AR, Jones DR, Reifenberger JG, Sass LE, McInerney P, Thompson JF, Bowers J, Jarosz M, Milos PM. Direct RNA sequencing. Nature. 2009; 461:814-818. [PubMed: 19776739]

Proudfoot N, O'Sullivan J. Polyadenylation: a tail of two complexes. Current biology : CB. 2002; 12:R855-857. [PubMed: 12498707]

Proudfoot NJ. Ending the message: poly(A) signals then and now. Genes \& development. 2011; 25:1770-1782. [PubMed: 21896654]

Sandberg R, Neilson JR, Sarma A, Sharp PA, Burge CB. Proliferating cells express mRNAs with shortened $3^{\prime}$ untranslated regions and fewer microRNA target sites. Science. 2008; 320:16431647. [PubMed: 18566288]

Shepard PJ, Choi EA, Lu J, Flanagan LA, Hertel KJ, Shi Y. Complex and dynamic landscape of RNA polyadenylation revealed by PAS-Seq. Rna. 2011; 17:761-772. [PubMed: 21343387]

Singh P, Alley TL, Wright SM, Kamdar S, Schott W, Wilpan RY, Mills KD, Graber JH. Global changes in processing of mRNA $3^{\prime}$ untranslated regions characterize clinically distinct cancer subtypes. Cancer research. 2009; 69:9422-9430. [PubMed: 19934316]

Thomsen S, Azzam G, Kaschula R, Williams LS, Alonso CR. Developmental RNA processing of 3'UTRs in Hox mRNAs as a context-dependent mechanism modulating visibility to microRNAs. Development. 2010; 137:2951-2960. [PubMed: 20667912]

Tian B, Manley JL. Alternative cleavage and polyadenylation: the long and short of it. Trends in biochemical sciences. 2013; 38:312-320. [PubMed: 23632313]

Yoon OK, Brem RB. Noncanonical transcript forms in yeast and their regulation during environmental stress. Rna. 2010; 16:1256-1267. [PubMed: 20421314]

Zhuang F, Fuchs RT, Sun Z, Zheng Y, Robb GB. Structural bias in T4 RNA ligase-mediated 3'adapter ligation. Nucleic Acids Res. 2012; 40:e54. [PubMed: 22241775] 


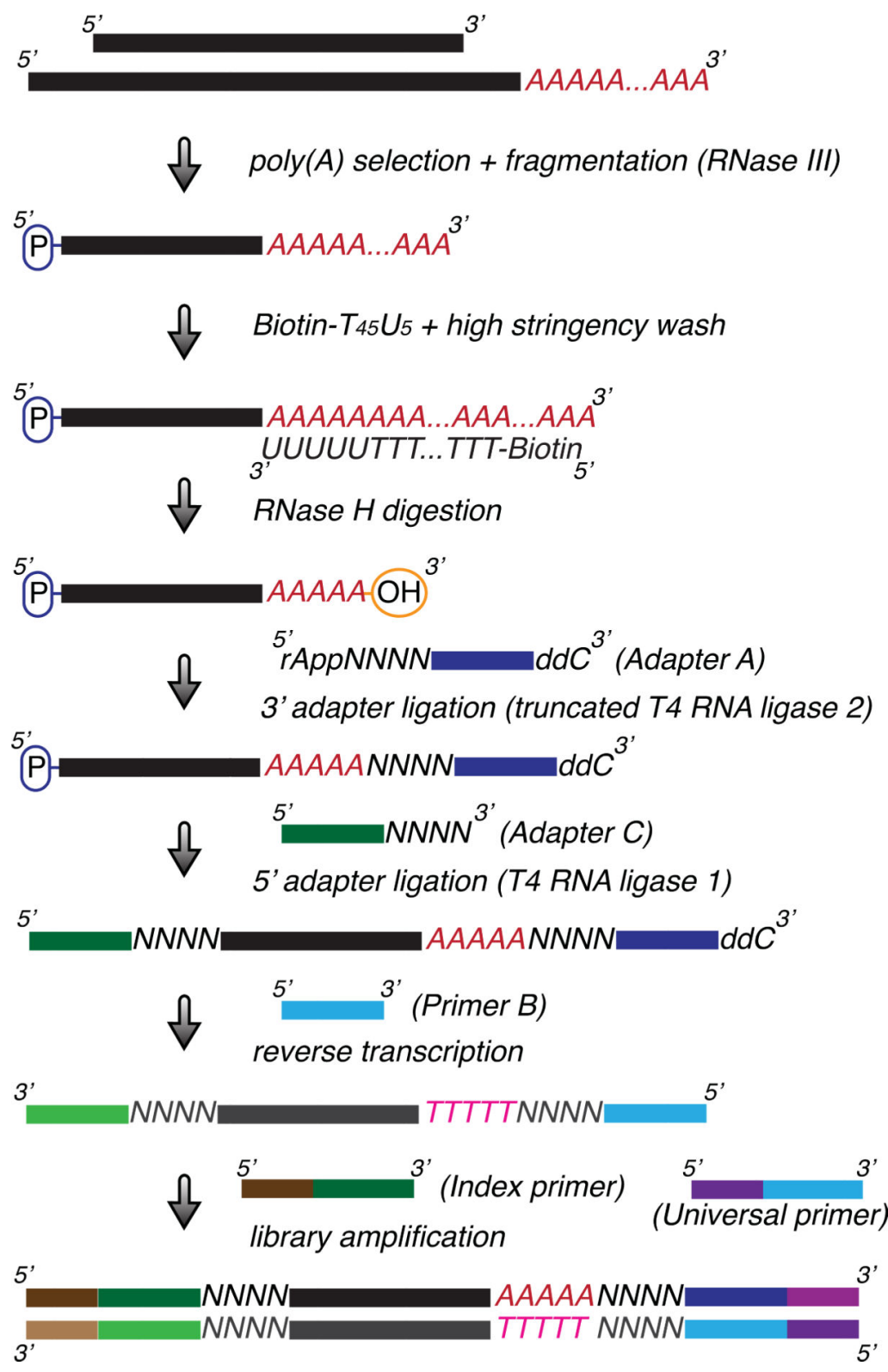

Figure 1.

Schematic of an indexed DNA library preparation for sequencing poly(A) sites (3' mRNA isoforms) on a genomic scale. Poly(A)-tailed RNAs are first enriched and fragmented by RNase III digestion. 3' polyadenylated RNA fragments captured by Dynabeads coated with a Biotin- $\mathrm{T}_{45} \mathrm{U}_{5}$ hybrid DNA/RNA oligo are subjected to RNase $\mathrm{H}$ digestion to generate RNA fragments containing 3' termini with only a few remaining As. After ligation of linkers (Adapters A and C) to both ends, the resulting RNA fragments are reverse-transcribed to yield single-stranded cDNA fragments using a primer (Primer B) based on the sequence of Adapter A. The cDNA fragments are in turn amplified with a universal primer (Universal primer) and a second primer containing the desired index (e.g., Index primer 1) to generate a double-stranded DNA library. The quality and quantity of the purified DNA library can be examined using the Agilent Bioanalyzer and Quantitative-PCR. 

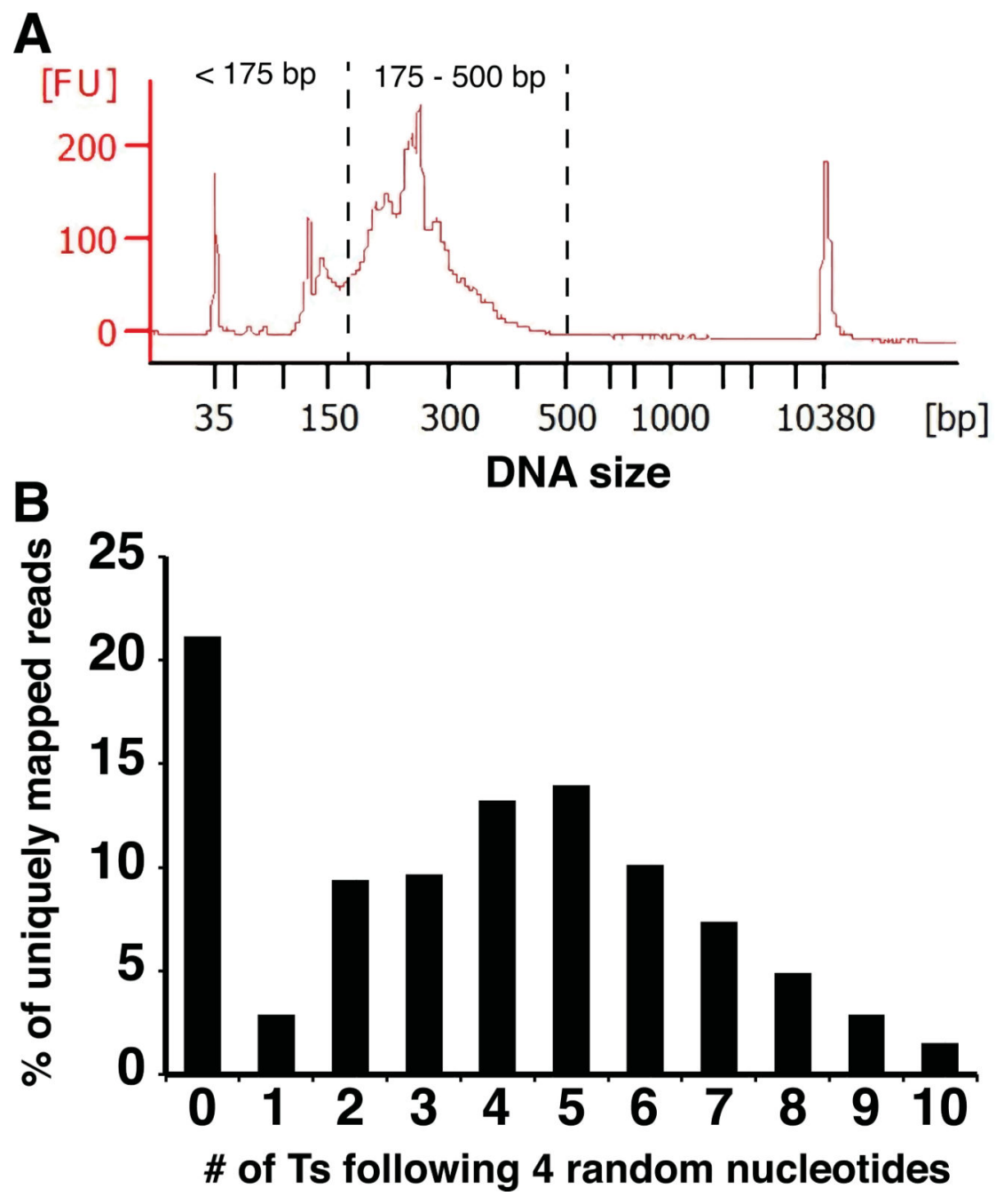

Figure 2.

(A) Agilent Bioanalyzer analysis (High-sensitivity DNA Kit) of a SPRI-beads-purified DNA library is shown. DNA fragments smaller than 175 bp include library DNAs with very short cDNA inserts, PCR primer dimers, and residual PCR primers. Gel purification is required to further extract only DNA fragments between $175 \mathrm{bp}$ and $500 \mathrm{bp}$ for Illumina sequencing. The DNA peaks at 35 bp and 10380 bp are high sensitivity DNA markers used in Agilent Bioanalyzer analysis. (B) Distribution of the number of consecutive Ts following four random nucleotides in uniquely mapped sequence reads. The stretch of Ts corresponds to the As remaining from poly(A) tails after RNase $\mathrm{H}$ digestion. Reads with no Ts are likely to be caused by RNase H over-digestion and contaminating non-3' RNA fragments. 

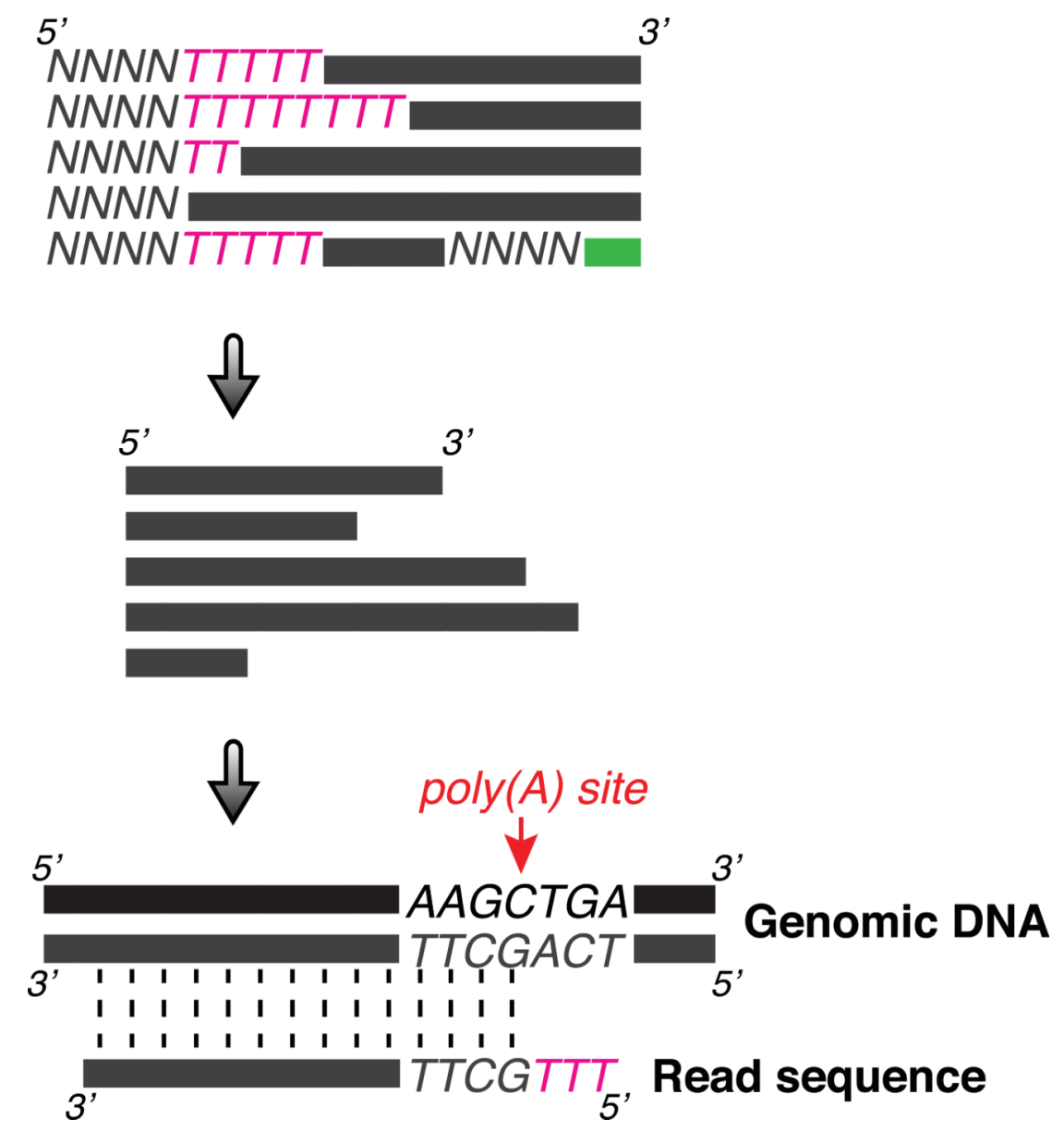

Figure 3.

Schematic of sequencing data processing to identify poly(A) sites. Raw reads are first trimmed at 5' end (and 3' end if necessary) and then aligned to the reference genome sequence. Poly(A) sites are defined by PASS reads, which are the uniquely mapped reads with at least two Ts not matched with genomic sequence. The last aligned position is considered as the poly(A) site. 


\section{Table 1}

Oligonucleotide Sequences

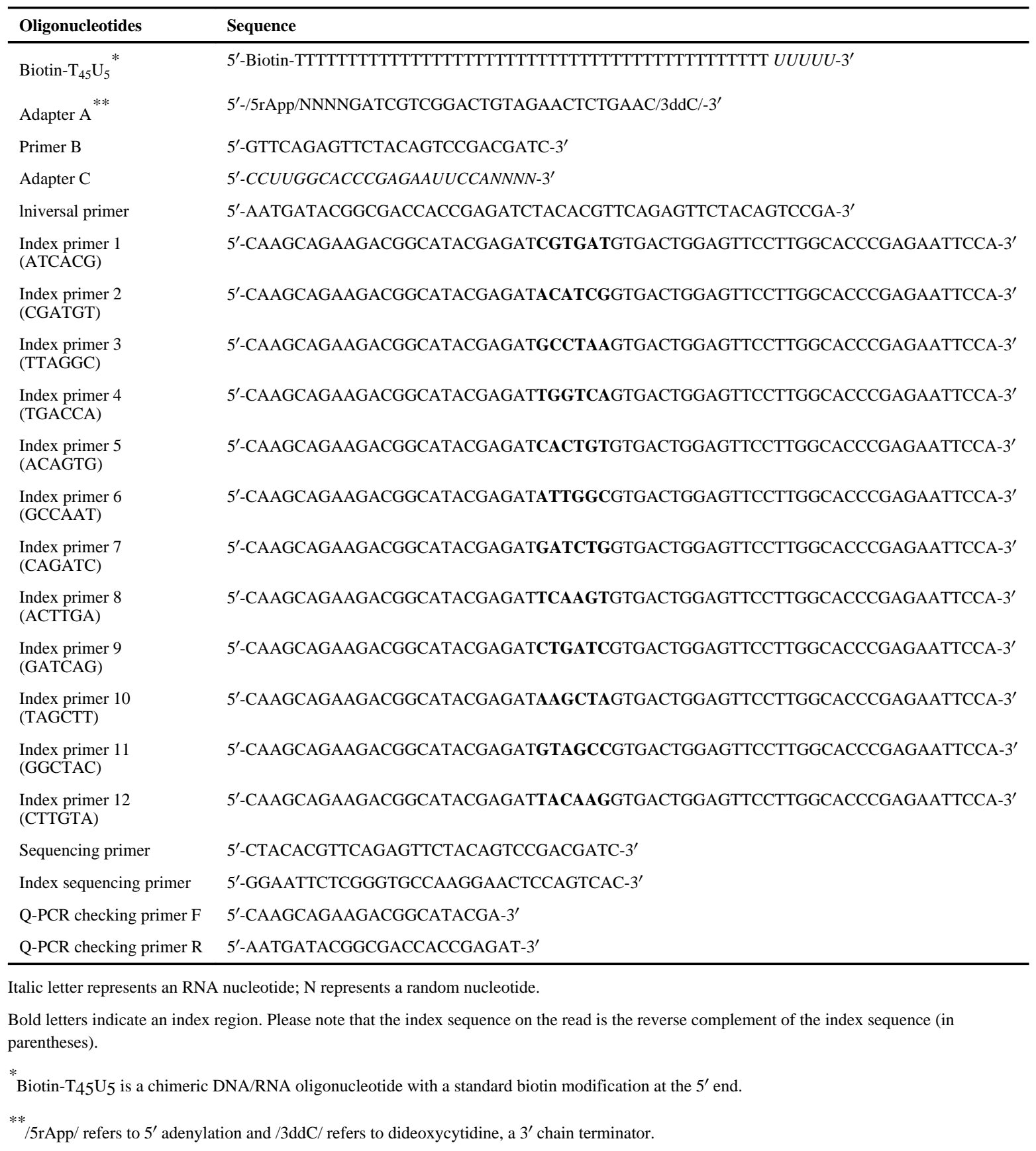

Curr Protoc Mol Biol. Author manuscript; available in PMC 2016 April 01. 